\title{
MENINGKATKAN PRODUKTIVITAS MASYARAKAT AKIBAT DAMPAK PANDEMI COVID-19 MELALUI PENYALURAN BANTUAN BERUPA BIBIT ITIK KEPADA PENGUSAHA PEMULA DI DESA DAREK
}

\author{
Oleh \\ Sri Maryanti'), I Gusti Ayu Oka Netrawati²), I Wayan Nuada ${ }^{3)}$, I Gusti Putu Bagus \\ Suastina $^{4)}$, Faezal ${ }^{5)}$, Syarifah Massuki Fitri ${ }^{6}$ ), Asri Oktiani ${ }^{7)}$ \& Suharti ${ }^{8}$ ) \\ 1,2,3,4,5,6,7,8 Sekolah Tinggi Ilmu Ekonomi 45 Mataram \\ Email : ${ }^{1}$ maryanti.sri88@ gmail.com, ${ }^{2}$ igaokanetrawati2017@gmail.com \& \\ 3.wayannuada@gmail.com
}

\begin{abstract}
Abstrak
Pandemi Covid-19 saat ini dipandang tidak lagi hanya mengancam kesehatan masyarakat, namun lebih jauh lagi, mengancam ekonomi dan sosial masyarakat. Sejak mewabah di awal tahun 2020 lalu hingga saat ini, perbaikan perekonomian masih menunjukan hasil yang belum memuaskan. Hal ini dikarenakan masih dibatasinya akses penerbangan yang merembet pada lesunya industri pariwisata. Belum lagi gelombang pemutusan kerja yang terjadi akhir-akhir ini. Maka dari itu, kami dari kelompok akademisi merasa terpanggil untuk turut memberikan solusi membantu masyarakat melalui Kegiatan Pengabdian Masyarakat (PKM). Desa Darek adalah salah satu diantara sekian banyak daerah yang mengalami keadaan ekonomi yang cukup sulit. Setelah melakukan kunjungan, diskusi dan berdialog dengan beberapa penduduk usia produktif, maka kami memutuskan untuk memberikan penyuluhan ternak itik sebagai solusi pemecahan masalah. Berdasarkan penyuluhan tersebut diketahui bahwa ternak itik merupakan usaha atau bisnis alternatif yang menjanjikan dan layak untuk dijalankan karena memberikan manfaat keuntungan finansial dan sosial (berdasar perhitungan Laba/Rugi dan analisis kelayakan usaha).Harapan kami kedepannya, masyarakat mampu mengembangkan usaha ternak itik dan tidak hanya mampu memenuhi kebutuhan secara mandiri, namun juga mampu meningkatkan kesejahteraan masyarakat di Desa.
\end{abstract}

Kata Kunci: Produktivitas, Pandemi Covid-19, Bibit Itik \& Desa Darek

\section{PENDAHULUAN}

Sejak virus Covid-19 mulai mewabah di seluruh dunia dan tidak terkecuali Indonesia pada awal tahun 2020 lalu, banyak tindakan yang dilakukan oleh pemerintah untuk mencegah terjadinya penularan Virus Corona yang malah justru bersinggungan dengan kesejahteraan Masyarakat. Misalnya saja, pembatasan perlintasan mobilitas orang dari luar maupun dalam negeri, kemudian program pembatasan sosial bersekala besar (PSBB) yang mengakibatkan sebagian besar masyarakat melakukan kegiatan seperti bekerja, beribadah dan bersekolah dari rumah atau dikenal dengan work from home (WFH). Kesemua hal ini seolah bagaikan dua sisi mata pisau, disisi lain dianggap mampu untuk menekan penyebaran virus yang membahayakan kesehatan, namun disisi lainnya mengganggu mata pencarian dan perekonomian masyarakat.(Maryanti et al., 2020)

Satu tahun berlalu sejak pandemi Covid-19 masuk ke Indonesia dan menyebar hampir keseluruh provinsi yang ada, tidak terkecuali Nusa Tenggara Barat (NTB). Banyak pergeseran-pergeseran ekonomi yang ditimbulkan oleh pandemi ini. Beberapa sektor bisnis andalan NTB yang ikut tergerus pandemi, seperti sektor pariwisata dan perdagangan. (Lipi.go.id, 2020). Hampir di semua daerah terjadi penutupan perusahaan sektor pariwisata, hotel, restoran, tempat hiburan dan bisnis-bisnis lainnya yang sangat tergantung pada pariwisata seperti UMKM dan jasa trasnportasi. Hal ini berimbas pada gelombang pemutusan hubungan kerja (PHK) 
secara besar-besaran, pengangguran yang meningkat, daya beli merosot sehingga terjadinya pergerakan ekonomi yang melambat. Saat ini pemperintah provinsi NTB secara umum telah berjuang untuk membangkitkan perekenomian yang sempat merosot dan mengalami kontraksi melalui beberapa stimulus-stimulus Ekonomi di daerah yang tepat sasaran. (Kemenkeu.go.id, n.d.)

Dalam rangka mendukung percepatan pengentasan dampak ekonomi akibat Covid-19, kami dari kaum akademisi di lingkungan kampus STIE 45 Mataram merasa ikut terpanggil untuk memberikan sumbangsih kepada masyarakat yang berada di Desa Darek, Kecamatan Praya barat Daya, Kabupaten Lombok Tengah. Dimana kegiatan ini dilakukan melalui penyaluran bibit itik kepada beberapa masyarakat usia produktif. Sama seperti permasalahan yang dihadapi daerah lainnya, Desa Darek juga memiliki sebagian besar penduduk usia produktif yang saat ini menganggur, karena sebelumnya merupakan tenaga keja Indonesia (TKI) yang bekerja diluar negeri seperti Malaysia dan Arab Saudi. Kedepannya kami berharap pengusaha pemula ini akan dapat mengembangkan diri dan mampu untuk memenuhi kebutuhan sendiri, sehingga kesejahteraan meningkat yang pada akhirnya akan membantu menggerakkan perekonomian di desa tersebut.

Adapun tujuan dari kegiatan Pengabdian Kepada Masyarakat ini adalah :

1. Mengurangi jumlah pengangguran yang ada di desa yang terjadi akibat dampak negatif dari Pandemi Covid-19

2. Memberikan motivasi kepada masyarakat desa usia produktif untuk tetap semangat dalam bekerja

3. Membantu masyarakat desa untuk memenuhi kebutuhan dasar secara mandiri

4. Membantu menggerakkan perekonomian di desa dan sekaligus meningkatkan kesejahteraan masyarakat desa
Adapun manfaat dari kegiatan Pengabdian Kepada Masyarakat ini adalah :

1. Mengetahui perhitungan harga pokok produksi dalam melakukan sebuah usaha

2. Mengetahui seberapa besar persentase keuntungan dalam rangka melakukan usaha

3. Mengetahui perhitungan Break Even Point (BEP) untuk penentuan layak atau tidaknya suatu usaha untuk terus dijalankan

\section{LANDASAN TEORI \\ Motivasi}

Menurut Robbins (P. Stephen Robbins \& Mary Coutler, 2016) mengartikan motivasi sebagai tahapan yang akan mengakibatkan kekuatan, arah dan upaya yang terus menerus bagi seseorang dalam rangka mencapai tujuan akhir yang diharapkan. Motivasi akan muncul karena ada beberapa kebutuhan yang belum terpuaskan atau adanya Hasrat yang diangankan. Komponen yang ada dalam motovasi mencakup unsur membangkitkan, mengarahkan, menjaga, menunjukkan entitas yang terus menerus disertai tujuan yang jelas.(Wibowo, 2016)

Disimpulkan dari beberapa teori diatas maka disimpulkan bahwa motivasi adalah pendorong yang berasal dari luar maupun dalam diri seseorang dengan harapan adanya aktivitas guna mencapai tujuan yang diarapkan.

\section{Produktivitas}

Produktivitas saat ini menjadi masalah yang dianggap sangat penting hal ini terjadi disebabkan oleh masyarakat yang sadar jika produktivitas merupakan alat menjadikan masyarakat lebih sejahtera. Kondisi ini menyebabkan banyak para ahli yang mengembangkan konsep dan definisi dari produktivitas beberapa pengertian dari produktivitas menurut para ahli.

Budiono (A.M. Sugeng Budiono, 2003) menjabarkan bahwa perbandingan antara output dan input merupakan produktivitas. Konsep tersebut diterapkan untuk perusahaan, industry dan pelaku perekonomian. Ringkasnya 
produktivitas adalah perbandingan dengan menghitung jumlah per sumberdaya yang digunakan selama proses terjadi.

Produktivitas merupakan perbandingan outout dan input dalam suatu proses produksi. Manajemen, sumber daya manusia, biaya produksi, peralatan dan sewa waktu merupakan komponen dari input, sedangkan output terdiri dari produksi, produk yang dijual, pendapatan, pangsa pasar, dan kerusakan dari produk.(Tb. Sjafri Mangkuprawira, 2011)

Faktor penting untuk mencapai produktivitas tinggi antara lain:

1. Keahlian dan manajemen yang bertanggung jawab

2. Kepemimpinan yang luar biasa

3. Kesederhanaan organisasi dan operational

4. Kepegawaian yang efektif

5. Tugas yang menantang

6. Perencanaan dan pengendalian tujuan

7. Pelatihan manajerial khusus

\section{Harga Pokok Produksi}

Terdapat dua metode dalam

menentukan harga pokok produksi yaitu sebagai berikut (Daljono, 2011):

\section{Full costing}

Full costing merupakan metode penentuan harga pokok produk dengan memasukkan semua biaya yang bersifat variabel maupun yang bersifat tetap terhadap produk. Metode full costing dapat di jabarkan sebagai berikut:

$\begin{array}{ll}\text { Biaya bahan baku } & \mathrm{xxx} \\ \text { Biaya tenaga kerja langsung } & \mathrm{xxx} \\ \text { Biaya overhead pabrik variable } & \mathrm{xxx} \\ \text { Biaya } \text { overhead pabrik tetap } & \underline{\mathrm{xxx}}\end{array}$

Harga pokok produksi

XXX

\section{Variabel Costing}

Variabel costing merupakan perhitungan harga pokok produk yang hanya memasukkan biaya produksi variabel. Biaya yang bersifat tetap terhadap produk (biaya overhead pabrik tidak tetap) dimasukkan sebagai biaya periode. Metode variabel costing dapat dijabarkan sebagai berikut :
Biaya bahan baku

$\operatorname{XXX}$

Biaya tenaga kerja langsung

Biaya overhead pabrik variable

$\mathrm{xxx}$

Harga pokok produksi

$\mathrm{XXX}$

\section{Analisis Kelayakan usaha}

Suatu kegiatan yang bertujuan untuk menilai apakah suatu bisnis atau usaha itu layak atau tidak untuk terus dijalankan, disebut dengan analisis kelayakan usaha. Analisis kelayakan usaha ini penting untuk dilakukan dalam rangka membantu pengambilan keputusan apakah akan menerima atau bahkan menolak suatu gagasan usaha. Kata "Layak" dalam hal ini mengandung makna usaha yang akan dijalankan tersebut dapat bermanfaat secara finansial ataupun sosial. Berikut adalah beberapa metode untuk menilai kelayakan usaha tersebut (Riki Suharda et al., n.d.) :

1. Return per Cost (R/C) Ratio

$\mathrm{R} / \mathrm{C}$ adalah perbandingan antara penerimaan penjualan dengan biaya-biaya yang dikeluarkan selama proses produksi hingga menghasilkan produk. Suatu Usaha atau bisnis diakatakan akan menguntungkan apabila nilai $\mathrm{R} / \mathrm{C}>1$. Semakin besar nilai $\mathrm{R} / \mathrm{C}$ semakin besar pula tingkat keuntungan yang akan diperoleh dari usaha tersebut. (Soekartawi, 2002)

\section{Break Even Point (BEP)}

Titik break even point atau titik pulang pokok dapat diartikan sebagai suatu keadaan dimana dalam operasinya perusahaan tidak memperoleh laba dan tidak menderita rugi (total penghasilan = total biaya). (Munawir, 2002). Pada dasarnya, sebuah usaha dinyatakan layak apabila penjualan atau produksi melebihi penjualan atau produksi pada saat mencapai titik impas, maka usaha tersebut telah mendatangkan keuntungan sehingga layak untuk diusahakan. (Soekartawi, 2002).

Secara umum BEP dapat dihitung melalui tiga metode yaitu metode persamaan, metode kontribusi unit dan metode grafis. Berikut perhitung menggunakan metode persamaan menurut Maruta (Maruta, n.d.).

Persamaan tersebut dapat diuraikan dalam rumus berikut :

$$
\mathrm{px}=\mathrm{a}+\mathrm{bx}
$$


Keterangan:

$\mathrm{p}=$ Harga jual per unit produk

$\mathrm{x}=$ Unit produk yang dijual/yang diproduksi

$\mathrm{a}=$ Total Biaya Tetap

$\mathrm{b}=$ Biaya variabel setiap unit produk

Dari persamaan diatas, dapat diuraikan menjadi rumus break even point sebagai berikut :

$\mathrm{BEP}\left(\right.$ Rupiah) $=\frac{\mathrm{a}}{1-\left[\frac{\mathrm{bx}}{\mathrm{px}}\right]}$

\section{MEODE}

Terdapat beberapa metode penyampaian materi yang digunakan dalam kegiatan ini, yaitu :

a. Metode ceramah yaitu metode menyampaikan informasi secara lisan dengan cara memaparkan materi yang telah disusun sebelumnya

b. Metode Tanya jawab, metode ini dilakukan untuk mengukur tingkat pemahaman dan respon peserta terkait dengan materi atau pembahasan yang dipaparkan.

c. Metode Diskusi yaitu metode ini dilakukan untuk bersama-sama mencari solusi dari setiap permasalahan yang dihadapi oleh peserta.

\section{HASIL DAN PEMBAHASAN Keadaan Demografis}

Desa Darek merupakan salah satu diantara sepuluh Desa yang terletak di kecamatan Praya Barat Daya. Kecamatan ini sendiri merupakan wilayah pemekaran dari kecamatan Praya Barat, dimana bagian sebelah utara berbatasan dengan wilayah Kecamatan Jonggat, di bagian selatan berbatasan dengan Samudra Indonesia. Sedangkan di bagian timur dan barat berbatasan dengan Kecamatan Praya Barat dan Kabupaten Lombok Barat. Sementara itu, dari segi penggunaan tanah, sekitar 64 persen dari luas wilayah Praya Barat
Daya merupakan tanah kering, sisanya adalah tanah sawah. (Profil Daerah|Website Resmi Kabupaten Lombok Tengah, n.d.).

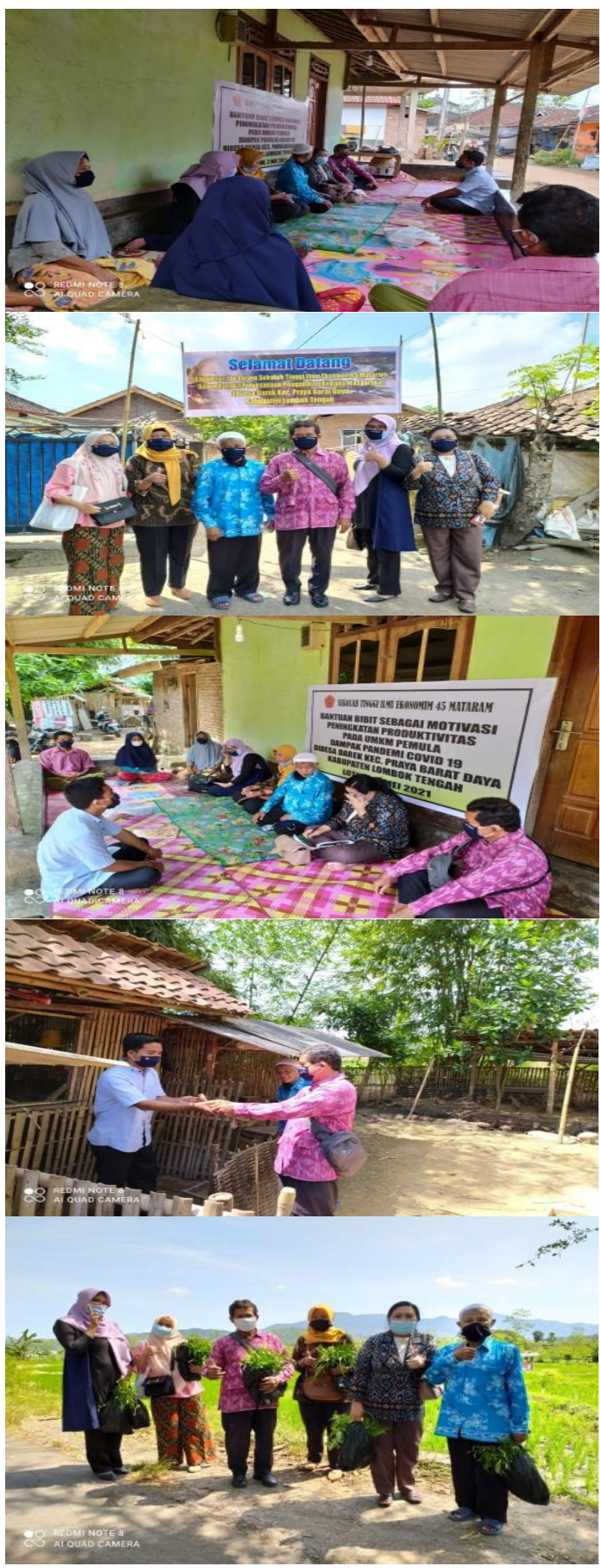


Desa Darek sendiri terdiri dari 11 Dusun, yang masing-masing dipimpin oleh Kepala Dusun. Sedangkan, terkait dengan pemanfaatan lahan seperti yang telah dipaparkan di atas, tidak heran sebagian besar kegiatan ekonomi masyarakat di Desa Darek masih didominasi sektor pertanian. Hampir 75 $\%$ wilayahnya terdiri dari lahan persawahan yang merupakan mata pencaharaian penduduk. Berikut adalah Jumlah Penduduk menurut mata pencaharian Penduduk. (Profil Desa Darek Kabupaten Lombok Tengah - Penelusuran Google, n.d.)

Tabel 1. Jumlah Penduduk menurut mata pencaharian Penduduk.

\begin{tabular}{|l|l|l|}
\hline No & Jenis Mata Pencaharian & $\begin{array}{l}\text { Jumlah } \\
\text { Orang }\end{array}$ \\
\hline 1. & $\begin{array}{l}\text { Pegawai Negeri Sipil } \\
\text { (PNS) }\end{array}$ & 137 \\
\hline 2. & TNI/Polri & 52 \\
\hline 3. & Pegawai Swasta & 186 \\
\hline 4. & Pedagang & 164 \\
\hline 5. & Pertukangan & 71 \\
\hline 6. & Jasa & 88 \\
\hline 7. & Buruh Tani & 1.876 \\
\hline \multicolumn{2}{|c|}{ Dari segi sosial budaya termasuk } \\
\hline
\end{tabular}
didalamnya adalah pendidikan. Banyak masyarakat yang berada di Desa Darek mempunyai batasan pendidikan hanya sampai pada tingkat SMP (Sekolah Menengah Pertama). Akibatnya masayarakat tersebut mencari pekerjaan di Luar Negeri, terutama di Malasia dan Arab Saudi. Mereka memilih jalan tersebut karena tidak mampu bersaing dengan yang lain, dan untuk menyelamatkan perekonomian keluarga. (Profil Desa Darek Kabupaten Lombok Tengah - Penelusuran Google, n.d.). Disisi lain, selama masa Pandemi Covid-19, terhitung sejak tahun 2020 hingga saat ini memasuki tahun 2021 terjadi moratorium atau penghentian sementara sampai batas waktu yang belum diketahui untuk lalu lintas orang yang akan berangkat ke Luar Negeri. Belum lagi penduduk yang semula memiliki mata pencaharian sebagai pegawai swasta dan sejenisnya yang harus mengalami pemutusan hubungan kerja. Hal ini menjadi beban baru bagi setiap wilayah khususnya Desa
Darek dan membutuhkan kerjasama dari berbagai pihak untuk menemukan solusinya.

\section{Perhitungan Laba}

Tabel 2. Biaya Pembuatan Kandang dan Peralatan 50 Ekor Itik Peternak Itik di Desa Darek

\begin{tabular}{|r|l|r|l|l|l|}
\hline $\begin{array}{l}\mathrm{N} \\
\mathrm{o}\end{array}$ & Uraian & $\begin{array}{l}\text { Jum } \\
\text { lah }\end{array}$ & Unit & $\begin{array}{l}\text { harga per unit } \\
(\mathrm{Rp})\end{array}$ & $\begin{array}{c}\text { total } \\
(\mathrm{Rp})\end{array}$ \\
\hline 1 & Bambu & 20 & $\begin{array}{l}\text { Bata } \\
\text { ng }\end{array}$ & 20,000 & 400,000 \\
\hline 2 & Asbes & 6 & $\begin{array}{l}\text { Lem } \\
\text { bar }\end{array}$ & 20,000 & 120,000 \\
\hline 3 & $\begin{array}{l}\text { Paku } \\
\text { usuk }\end{array}$ & 1 & $\mathrm{Kg}$ & 10,000 & 10,000 \\
\hline 4 & Paku reng & 1 & $\mathrm{Kg}$ & 10,000 & 10,000 \\
\hline 5 & $\begin{array}{l}\text { Ongkos } \\
\text { angkut }\end{array}$ & 1 & $\mathrm{Kali}$ & 50,000 & 50,000 \\
\hline 6 & $\begin{array}{l}\text { Peralatan } \\
\text { pakan }\end{array}$ & 1 & Set & 50,000 & 50,000 \\
\hline \multicolumn{7}{|c|}{ Total } & & & 640,000 \\
\hline
\end{tabular}

Tabel 3. Harga Pokok Produksi Pemeliharaan Itik 50 Ekor Sampai Panen Peternak Itik di Desa Darek

\begin{tabular}{|r|l|c|}
\hline No & Uraian & Biaya $(\mathrm{Rp})$ \\
\hline 1 & Biaya pakan & 935,000 \\
\hline 2 & Penyusutan kandang $=$ & \\
\hline & $(640000 / 5) *(2 / 12)$ & 21,333 \\
\hline 3 & Resiko kematian itik $=$ & \\
\hline & $(50$ X 6\% $) \times 7,500$ & 22,500 \\
\hline & Jumlah & 978,833 \\
\hline
\end{tabular}

Resiko kegagalan ternak itik akibat kematian sebesar $6 \%$, hal ini diketaui dari pengalaman peternak itik yang sebelumnya, dimana diantara 50 ekor itik terdapat rata-rata 3 ekor itik yang mati. Hal ini juga didasarkan pada tingkat ketahanan itik yang jauh lebih kuat apabila dibandingkan dengan ternak ayam.

Berdasarkan harga pasar yang berlaku saat ini, harga jual Itik per 3 ekor di tempat (pembeli yang langsung mendatangi peternak itik) $=$ Rp 100.000.,

Tabel 4. Laporan Laba/Rugi Pemeliharaan Itik Sampai Panen

\begin{tabular}{|r|l|c|}
\hline $\begin{array}{l}\text { N } \\
\mathrm{o}\end{array}$ & Uraian & $\begin{array}{c}\text { Jumlah } \\
(\mathrm{Rp})\end{array}$ \\
\hline 1 & Penjualan= (50/3) X Rp 100,000 & $1,700,000$ \\
\hline & Harga Pokok Produksi 50 Ekor & \\
2 & Itik & 978,833 \\
\hline 3 & Laba Kotor & 721,167 \\
\hline
\end{tabular}


Berdasarkan perhitungan di atas, maka didapatkan laba sebesar Rp 721,167., yang artinya ternak itik memiliki keuntungan sebesar $73,7 \%$ dari biaya modal yang dikeluarkan. Hal ini berarti ternak itik merupakan usaha yang cukup menjanjikan dengan keuntungan di atas $50 \%$ dan resiko kegagalan yang relatif rendah.

Disebut laba kotor karena belum dihitung biaya tenaga kerja. Usahanya masih tergolong usaha sampingan belum menjadi usaha pokok. Bila pemeliharaan itiknya ditingkatkan misalnya 4 kali lipat menjadi $6 \mathrm{x}$ 50 ekor $=300$ ekor, Butuh 1 orang tenaga kerja untuk membantu. Misalnya gajinya dihitung rp $1,500,000,-$ per bulan, maka laba bersih sebelum pajak adalah sebagai berikut.

Tabel 5. Perhitungan Laba Bersih Pemeliharaan 300 Ekor Itik Peternak Itik Di Desa Darek

\begin{tabular}{|c|l|c|}
\hline No & Keterangan & Jumlah (Rp) \\
\hline 1. & Laba kotor $=6$ x rp 721,167 & $4,327,002$ \\
\hline & $\begin{array}{l}\text { Beban tenaga kerja } 2 \times \text { rp } \\
\text { 2. }\end{array}$ & $3,500,000,-$ \\
\hline 3. & Laba bersih sebelum pajak & $1,327,002$ \\
\hline
\end{tabular}

Berdasarkan perhitungan di atas, setelah biaya tenaga kerja juga ikut dihitung maka terdapat laba sebelum pajak sebesar $\mathrm{Rp}$ $1,327,002$.

\section{Analisis Kelayakan Usaha Ternak Itik di Desa Darek}

Analisis Kelayakan Usaha Ternak untuk 300 Itik

1. $\mathrm{R} / \mathrm{C}$ ratio

Return per Cost Ratio(R/C ratio) adalah perbandingan nisbah antara total penerimaan dan total biaya. Berdasar besar penerimaan yang diterima oleh peternak pada akhir periode produksi, dapat dilihat kelayakan usaha ternak itik secara ekonomi. Nilai $\mathrm{R} / \mathrm{C}$ ratio usaha ternak itik di Desa Darek dapat dituliskan secara matematika sebagai berikut:

$$
\begin{aligned}
\text { RC/Ratio } & =\frac{\text { Total Penerimaan }}{\text { Total Biaya }} \\
& =\frac{6 \times 1.700 .000}{(6 \times 978.833)+(3.000 .000)} \\
& =10.200 .000 /(5.872 .998)+3.000 .000 \\
& =10.200 .000 / 8.872 .998 \\
& =1,150
\end{aligned}
$$

Dari hasil perhitungan dapat diketahui bahwa setiap Rp. 1.000 biaya yang dikeluarkan peternak dalam usaha ternak itik, maka akan memberikan penerimaan sebesar Rp. 1.150. Kelayakan suatu usaha diketahui dengan membandingkan nilai $\mathrm{R} / \mathrm{C}$ ratio dengan nilai konstanta yakni satu. Suatu usaha dikatakan layak apabila nilai $\mathrm{R} / \mathrm{C}$ ratio lebih besar dari satu dan jika nilai $\mathrm{R} / \mathrm{C}$ ratio lebih kecil dari satu maka usaha tersebut dikatakan tidak layak. Sementara dari perhitungan di atas diperoleh nilai $\mathrm{R} / \mathrm{C}$ ratio di daerah pengabdian adalah 1,150 atau lebih besar dari satu, maka dapat disimpulkan bahwa secara ekonomi usaha peternakan itik di daerah pengabdian layak untuk diusahakan.

\section{Break Even Point (BEP)}

Perhitungan BEP dilakukan dengan metode persamaan, dimana metode ini didasarkan pada pendekatan laporan laba rugi

\begin{tabular}{|c|c|c|c|c|c|}
\hline $\begin{array}{l}\mathrm{N} \\
\mathrm{o}\end{array}$ & Uraian & $\begin{array}{l}\text { Juml } \\
\text { ah }\end{array}$ & Unit & $\begin{array}{l}\text { harga per unit } \\
\text { (Rp) }\end{array}$ & total $(\mathrm{Rp})$ \\
\hline 1 & Bambu & 20 & $\begin{array}{l}\text { Bata } \\
\text { ng }\end{array}$ & 20,000 & 400,000 \\
\hline 2 & Asbes & 6 & $\begin{array}{l}\text { Lem } \\
\text { bar }\end{array}$ & 20,000 & 120,000 \\
\hline 3 & Paku usuk & 1 & $\mathrm{Kg}$ & 10,000 & 10,000 \\
\hline 4 & Paku reng & 1 & $\mathrm{Kg}$ & 10,000 & 10,000 \\
\hline 5 & $\begin{array}{l}\text { Ongkos } \\
\text { angkut }\end{array}$ & 1 & Kali & 50,000 & 50,000 \\
\hline 6 & $\begin{array}{l}\text { Peralatan } \\
\text { pakan }\end{array}$ & 1 & Set & 50,000 & 50,000 \\
\hline \multicolumn{4}{|c|}{ Total } & & 640,000 \\
\hline
\end{tabular}
yang sudah dihitung sebelumnya.

Berdasarkan perhitungan biaya tetap dan biaya variable yang sudah diklasifikasi, maka perhitungan BEP untuk ternak itik di Desa Darek dalah sebagai berikut :

1. Biaya tetap yang dikeluarkan per 3 bulan sebesar Rp 640.000, terdiri dari : 
2. Biaya variable per ekor itik dalam kurun waktu 3 bulan (sampai panen) Rp 19.577, terdiri dari :

\begin{tabular}{|r|l|c|}
\hline No & Uraian & Biaya (Rp)/ Ekor itik \\
\hline 1 & Biaya pakan & 18.700 \\
\hline 2 & Penyusutan kandang & 427 \\
\hline 3 & Resiko kematian itik & 450 \\
\hline & Jumlah & 19.577 \\
\hline
\end{tabular}

3. Harga jual per ekor itik Rp 33.333,3 (didapatkan dari harga jual per 3 ekor itik $=\mathrm{Rp}$ 100.000)

4. Kapasitas Produksi penuh 300 ekor itik

Dari data tersebut dapat dihitung berapa jumlah BEP dalam rupiah, sebagai berikut :

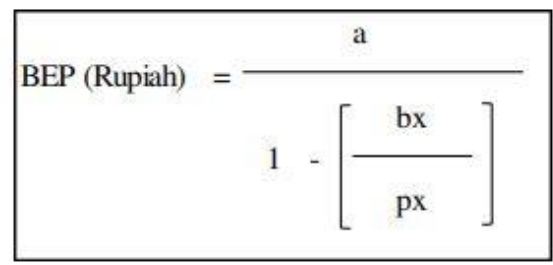

Di mana:

BEP $($ Rupiah $)=$ Break Even Point dalam Rupiah

$\mathrm{a}=$ Biaya Tetap

$\mathrm{bx}=$ Biaya Variabel per Unit $\mathrm{x}$ Kapasitas produksi Penuh

px = Harga Jual per Unit $\mathrm{x}$ Kapasistas Produksi Penuh

Jadi :

BEP (Rupiah) = 640.000/1-

(19.577x300/33.333,3x300)

$\operatorname{BEP}($ Rupiah $)=640.000 / 1-(0,59)$

BEP $($ Rupiah $)=640.000 / 0,41$

$\mathrm{BEP}($ Rupiah $)=1.560 .976$

Perhitungan BEP unit adalah sebagai berikut :

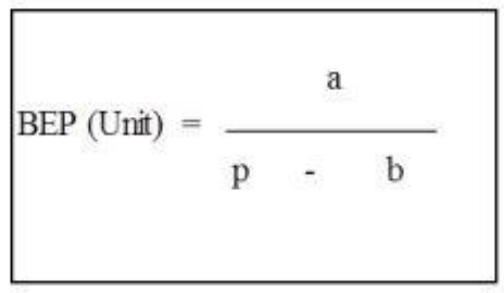

Di mana:
BEP (unit) $=$ Break Even Point dalam unit

$\mathrm{a}=$ Biaya Tetap

$\mathrm{b}=$ Biaya Variabel per Unit

$\mathrm{p}=$ Harga Jual per Unit

jadi :

$\mathrm{BEP}$ (unit) $=640.000 /(33.333,3-19.577)$

BEP (unit) $=640.000 / 13.756,3$

$\mathrm{BEP}$ (unit) $=46.5$

$\mathrm{BEP}($ unit $)=47$ ekor

Dari hasil hitungan Break Even Point (BEP) di atas menunjukkan bahwa apabila peternak mau mendapat keuntungan, maka harus memproduksi atau menjual itik dalam jumlah di atas 47 ekor sampai batas kapasitas penuh yaitu 300 ekor. Apabila peternak menjual itik di bawah jumlah 47 ekor dipastikan peternak menderita kerugian. Misalnya apabila peternak memproduksi sebanyak 100 ekor maka dapat dihitung sebagai berikut:

Penjualan 100 ekor $\mathrm{x} \operatorname{Rp} 33.333,3=\mathrm{Rp}$ 3.333.333

Biaya = biaya tetap + biaya variabel + $(100 \times 19.577)=\operatorname{Rp} 2.617 .277$

Sehingga laba/keuntungan yang didapatkan : Penjualan - biaya $=$ Rp3.333.333- $\mathrm{Rp}$ 2.617.277 = Rp 716.056

Jika sebaliknya, yaitu peternak memproduksi atau menjual itik dibawah 47 ekor, maka akan menderita kerugian.

\section{PENUTUP \\ Kesimpulan}

1. Desa Darek yang sebagian besar lahannya merupakan lahan persawahan sangat cocok untuk dijadikan lokasi ternak itik sebagai usaha atau bisnis alternatif yang patut untuk dijalankan

2. Berdasarkan hasil perhitungan laba rugi seperti yang telah diuraikan di atas menunjukkan usaha atau bisnis ternak itik di Desa Darek cukup menjanjikan keuntungan yang menarik. Hal ini bisa dimanfaatkan oleh penduduk usia produktif sekitar sebagai kegiatan yang 
dapat menghasilkan keuntungan terutama di masa pandemi.

3. Dari segi analisis kelayakan usaha, usaha ternak itik di Desa Darek berdasarkan dua metode analisi yaitu $\mathrm{R} / \mathrm{C}$ ratio maupun $\mathrm{BEP}$ menunjukkan hasil yang baik dan layak untuk dijasikan bisnis karena menguntungkan secara finansial dan sosial.

\section{Sarann}

1. Diperlukan suatu wadah atau perkumpulan yang berbadan hukum seperti koperasi untuk menampung para peternak itik di Desa Darek agar memiliki bargaining power untuk bisa menentukan harga jual yang lebih layak

2. Diperlukan keterampilan tambahan bagi para peternak itik Desa Darek untuk menjual itik yang sudah siap olah, sehingga memiliki nilai tambah yang lebih.

\section{DAFTAR PUSTAKA}

[1] A.M. Sugeng Budiono. (2003). Bunga Rampai Hiperkes dan Kesehatan Kerja. Badan Penerbit Universitas Diponegoro.

[2] Daljono. (2011). Akuntansi Biaya, Penentuan Harga Pokok dan Pengendalian (Edisi Ketiga). Badan Penerbit Universitas Diponegoro.

[3] Kemenkeu.go.id. (n.d.). Ini Paket Stimulus Fiskal Jilid 2 Antisipasi Dampak Negatif Virus Corona Pada Ekonomi. Retrieved May 2, 2020, from https://www.kemenkeu.go.id/publikasi/ber ita/ini-paket-stimulus-fiskal-jilid-2antisipasi-dampak-negatif-virus-coronapada-ekonomi/

[4] Lipi.go.id. (2020, February). Dampak Virus Corona pada Laju Ekonomi Indonesia 2020.

http://lipi.go.id/berita/single/Dampak-

Virus-Corona-pada-Laju-Ekonomi-

Indonesia-2020/21963

[5] Maruta, H. (n.d.). ANALISIS BREAK EVEN POINT (BEP) SEBAGAI DASAR PERENCANAAN LABA BAGI MANAJEMEN. 20.
[6] Maryanti, S., Netrawati, I. G. A. O., \& Nuada, I. W. (2020). PANDEMI COVID19 DAN IMPLIKASINYA PADA PEREKONOMIAN NTB. MEDIA BINA ILMIAH, 14(11), 3497-3508. https://doi.org/10.33758/mbi.v14i10.573

[7] Munawir, S. (2002). Akuntansi Keuangan dan Manajemen (Edisi Pertama). BPFE.

[8] P. Stephen Robbins, \& Mary Coutler. (2016). Human Resources Management (Edisi 16). Salemba Empat.

[9] Profil Daerah | Website Resmi Kabupaten Lombok Tengah. (n.d.). Retrieved May 15, 2021, from https://lomboktengahkab.go.id/halaman/pr ofil-daerah

[10]profil desa darek kabupaten lombok tengah-Penelusuran Google. (n.d.). Retrieved May 15, 2021, from https://www.google.com/search?q=profil+ desa+darek+kabupaten+lombok+tengah\& safe $=$ strict\&ei $=x 7$ ufYLzFE4nFz7sPjaCU wAw\&oq=profil+desa+darek\%2C+\&gs_1 $\mathrm{cp}=\mathrm{Cgdnd} 3 \mathrm{Mtd} 216 \mathrm{EAEYADIFCCEQoAE}$ yBQghEKABOgcIABBHELADOgIIADo GCAAQFhAeOgQIABBDOgIILjoFCAA QsQM6BAgAEAM6CAgAELEDEIMBO ggIABDHARCvAVDZNlikkgFg55MCaA FwAngAgAHA4gBtzuSAQwwLjIyLjkuMS4zLjGYAQ CgAQGqAQdnd3Mtd216yAEIwAEB\&scl ient=gws-wiz

[11]Riki Suharda, Lily Fauzia, \& Emalisa. (n.d.). ANALISIS KELAYAKAN USAHA TERNAK ITIK (Studi Kasus Desa Percut, Kec. Percut Sei Tuan, Kab. Deli Serdang).

[12] Soekartawi. (2002). Prinsip Dasar Ekonomi Pertanian Teori dan Aplikasi. PT. Raja Grafindo.

[13] Tb. Sjafri Mangkuprawira. (2011). Manajemen Sumber Daya Manusia Strategik. Ghalia Indonesia.

[14] Wibowo. (2016). Manajemen Kinerja (Edisi Kelima). PT.Rajagrafindo Persada. 